\title{
Foreign Direct Investment Expansion and Tourism Receipts: Econometrics Analysis and Forecasts in the case of Sri Lanka
}

\author{
Dr. Abdul Majeed Mohamed Mustafa
}

\begin{abstract}
Tourism has become an important economic activity in all the countries of the world. It creates direct and indirect impact on the economy. Foreign Direct Investment (FDI) is considered as one of the routes through which developing countries can reach tourism. In this regard, Sri Lanka offers attractive investment opportunities for foreign companies and has adopted a number of policies to attract FDI into the country. The aim of this study is to investigate the relationship between tourism and Foreign Direct Investment in Sri Lanka. Annual data gathered for the period from 1978 to 2014 and forecasted data for the period from 2015 to 2016 were used for the study. Data were analyzed using E-Views. Augmented Dickey-Fuller is used for unit root test, while Engle-Granger is used for co-integration, whereas Granger causality test was employed to find the causal relationships. The empirical evidence shows that there is a statistically significant and positive relationship between tourism receipts and Foreign Direct Investment. Granger causality test revealed that there exists two-way causality implying that Foreign Direct Investments helped to boost tourism sector while tourism earnings stimulated the Foreign Direct Investment.
\end{abstract}

Keywords: Tourism; Foreign Direct Investment

\section{Introduction}

In developing countries, FDI helps to tackle socioeconomic problems such as unemployment, deficit in balance of payment, lack of capacity, scarcity of foreign exchange, and poor technological ability, etc. Many analysts express the belief that the promotion of FDI inflow into developing economies is a key solution to resolve above socio-economic problems faced by host countries like Sri Lanka (Ram et al, 2002). Further, there are many other advantages from FDI such as new technology, management, marketing management, global market prices, linkage with local economy, transfer of technical skills, relation with international market, capital formation, favorable balance of payment, infrastructure development, tourism development and resource utilization. Tourism is increasingly as an attractive development option for many parts of the developing world. In some developing nations, it may in fact be the only viable means of stimulating development. Developing nations are seeking the potential benefits of tourism, such as increased income, foreign exchange, employment and economic diversification; nevertheless, these developmental benefits may in fact fail to materialize. In entering this global competitive industry, developing countries may find tourism benefits only the local elite or multinational corporations, or is achieved at significant economic, social or environmental costs. (David \& Richard, 2010) Sri Lanka received Rs.24 Millions of FDI in 1978, and it reached Rs.110,208 Millions of FDI in 2013 (Central Bank of Sri Lanka, 2014). Tourism industry led to income received from tourism was Rs. 18,863 million in 2001, 40,133 Million in 2009 and 221,147 Million in 2013 (Tourism Development Authority, 2013).

\section{Literature Review}

This review provides some fundamental ideas to analysis the impact of foreign direct investment on tourism sector. Craigwell \& Winston (2007) did a research on "Foreign Direct Investment and Tourism in SIDS: Evidence from Panel Causality Tests". This paper discussed the causal relationship between foreign direct investment and tourism in Small Island Developing States (SIDS). This study applied panel causality methods to investigate the relationship between foreign direct investment and tourism in Small Island Developing States (SIDS). The study titled on "Foreign Direct Investment and the Tourism Industry: the Case of China" by Dimitrios et.al (2007), analysed current state of FDI in China and the impact in tourism sector and identified the FDI inflow in the tourism sector has been supported by the growth of inward tourism and consumption. Srinivas (2008) in his research titled "A study on Foreign Direct Investment (FDI) in Indian Tourism", illustrated the impact of FDI on Indian tourism industry and the study highlights the reasons for low FDI rate in the Indian tourism. In this study, the researcher identified one of the most notable features of economic globalization has been the increased importance of foreign direct investment around the world. Moore \& Craigwel (2008) on "Foreign 
Direct Investment and Tourism in SIDS: Evidence from Panel Causality Test", applied panel causality methods to investigate the relationship between foreign direct investment and tourism in Small Island Developing States . The study underlined the results of the homogenous and instantaneous causality tests suggested that there is a bidirectional causal relationship between the variables. In the Indian context, Selvanathan et.al (2009) investigated the casual relationship between foreign investment and the number of foreign tourist arrivals in India. The study titled on "causality between foreign direct investment and tourism: Empirical Evidence from India" revealed that the development of the tourism sector needs investment in many forms and FDI is one such source. They argued that this introduces a causal link from FDI to tourist arrivals as this attracts greater numbers of visitors due to better amenities. Chen (2010) analyzed the "influence of FDI on China's Tourism Industry". This study discussed the influence of foreign direct investment in China's tourism industry since the late 1970s, when the Government reopened China to foreign direct investment into the county. The aim of the study was to find out the role of FDI on China's tourism industry. In this study, Chen had used both the comparative method and the case study approach to analysis and realize the role of foreign direct investment in China's tourism industry during the last few decades. The study discussed various aspects of the influence of foreign direct investment on China's tourism industry. The study of Georgantopoulos (2013) on "Tourism Expansion and Economic Development: Var/Vecm Analysis and Forecasts for the Case of India", was an empirical investigation and validity of the so-called "Tourism-Led Growth Hypothesis" (TLGH) supporting in most cases direct effect from tourism activity to growth and suggesting that tourism increases foreign exchange income, creates employment opportunities, and therefore triggers overall economic growth.

\section{Methodology}

Annual data gathered for the period from 1978 to 2013 and forecasted data for the period from 2014 to 2016 were used for the study. Data for this study have been collected from the Sri Lanka Tourism Development Authority Annual Statistical Report, World Investment Reports 1990 2014, Central Bank Annual Reports 1977 - 2014, The World Tourism Organization of the United Nations (UNWTO) and Economic and Social Statistics in Sri Lanka 1990 - 2014. From the following three forecasting models namely Linear model, Quadratic model, Exponential growth model. The Exponential growth model has been selected according to the Results for the forecasting statistics based on Mean Square Error (MSE), Mean Absolute error (MAE) and Mean Absolute Percentage Error (MAPE). On the basis of this, the data is forecasting from 2014 to 2016. This model, based on Georgantopouls (2013) formulated to examine the impact of foreign direct investment on tourism industry of Sri Lanka.

The following analytical functions given below test the forecast data contributed to performance of FDI to Tourism in Sri Lanka.

$$
\mathrm{TR}=\mathrm{FDI}, \mathrm{EX}, \mathrm{EFI}, \mathrm{D}
$$

Where $T R$ is tourism receipts, FDI is Foreign Direct Investment, EX is exchange rate EFI is Economic Freedom Index and D is Dummy variable.

In this study, Econometric Methodology - Multiple Regression and Correlation analysis have been used to analyze the data and Ordinary Least Square (OLS) is used to estimate the parameters of the model. Granger type causality test has been used to identify the direction of casual relationship between FDI and tourism industry and Unit root test has been applied to test the stationary properties of each variable. Co-integration analysis has been done to examine the long run (LR) relationship between FDI and tourism industry E-views7 econometrics software was used for the data analysis.

\section{Results and Discussion}

This part attempts to forecast the variables Foreign Direct Investment (FDI), Exchange Rate (EX), Economic Freedom Index (EFI) and Tourism Receipts (TR) with using forecasting data from 2014 to 2016. Further, the study analyses the impact of foreign direct investment on tourism industry in Sri Lanka for the period from the period of 1978 to 2016

Graphical presentation of data is very useful to identify the trend and underlying relationship between the variables TR and FDI. The Kernel Fit and Confidence ellipse graphs depicts that there is a strong positive relationship between

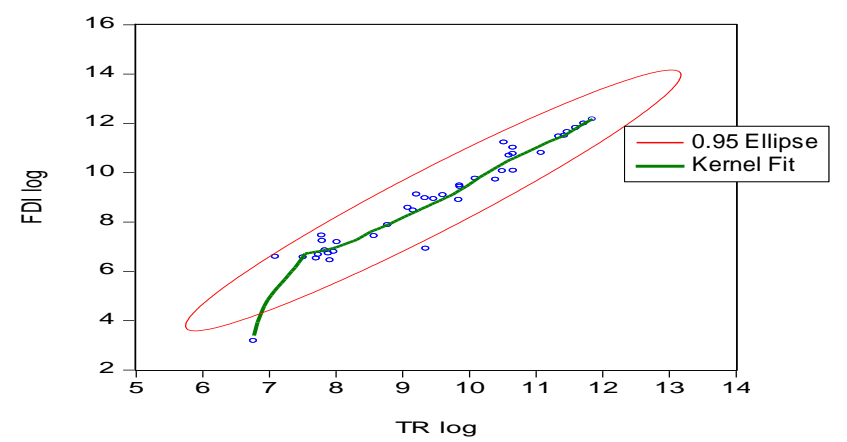

LTR and LFDI. And also show LTR and LFDI series are highly correlated.

Kernel Fit and Confidence ellipse Forecasting Model (LTR\&LFDI) 


\section{A. Result of Unit Root Test - ADF statistics Variables}

\begin{tabular}{|c|c|c|c|c|}
\hline Variables & ADF Test & Intercept & $\begin{array}{l}\text { Trend \& } \\
\text { Intercept }\end{array}$ & Decision \\
\hline LTR & $\begin{array}{l}\text { Level } \\
\text { First difference }\end{array}$ & $\begin{array}{c}-0.87 \\
-4.65^{*}\end{array}$ & $\begin{array}{l}-2.71 \\
-4.57 *\end{array}$ & $\begin{array}{l}\text { Non - Stationary } \\
\text { Stationary }\end{array}$ \\
\hline LFDI & $\begin{array}{l}\text { Level } \\
\text { First difference }\end{array}$ & $\begin{array}{l}-2.47 \\
-9.41^{*}\end{array}$ & $\begin{array}{l}-2.88 \\
-9.15^{*}\end{array}$ & $\begin{array}{l}\text { Non - Stationary } \\
\text { Stationary }\end{array}$ \\
\hline LEX & $\begin{array}{l}\text { Level } \\
\text { First difference }\end{array}$ & $\begin{array}{l}-2.09 \\
-5.12 *\end{array}$ & $\begin{array}{l}-0.81 \\
-5.92 *\end{array}$ & $\begin{array}{l}\text { Non - Stationary } \\
\text { Stationary }\end{array}$ \\
\hline LEFI & $\begin{array}{l}\text { Level } \\
\text { First difference }\end{array}$ & $\begin{array}{c}-0.85 \\
-6.75^{*}\end{array}$ & $\begin{array}{l}-2.52 \\
-6.66^{*}\end{array}$ & $\begin{array}{l}\text { Non - Stationary } \\
\text { Stationary }\end{array}$ \\
\hline
\end{tabular}

The Augmented Dickey-Fuller (ADF) Unit Root Tests are performed on both the levels and the first differences of the variables. The result of the unit root test (Augmented Dickey Fuller) for the variables ar presented in the above table. The Augmented Dickey Fuller Test results confirm that the time series data of the variables in the model are non-stationary in their levels. However these variables are stationary in their first difference. According to the Engle- Granger Co-integration analysis Unit Root Test for Residual of Co-integration Regression Equation was perform by Augmented Dickey-Fuller test. $\mathrm{ADF}$ test statistics $=-5.81, \mathrm{P}$ value $=0.0000$. As estimated residual is stationary. Variables LTR, LFDI, LEX, LEFI are co- integrated.

\section{B. Co-integration Regression Results}

\begin{tabular}{|l|c|c|c|}
\hline \multicolumn{1}{|c|}{ Variable } & Coefficient & t Value & Probability (p) \\
\hline $\boldsymbol{\beta}_{0}$ (Intercept ) & 9.978796 & 1.816398 & $\mathbf{0 . 0 7 8 7} * * *$ \\
\hline $\begin{array}{l}\text { ForeignDirect } \\
\text { Investment (LFDI) }\end{array}$ & 0.116437 & 2.562377 & $\mathbf{0 . 0 1 5 3} * *$ \\
\hline $\begin{array}{l}\text { Exchange Rate (LEX) } \\
\text { Economic Freedom Index } \\
\text { (LEFI) }\end{array}$ & 1.460388 & 7.243345 & $\mathbf{0 . 0 0 0 0 *}$ \\
\hline Dummy variable(D) & -1.818122 & -1.538058 & $\mathbf{0 . 1 3 3 9}$ \\
\hline AR(1) & 0.379497 & 3.552659 & $\mathbf{0 . 0 0 1 2} *$ \\
\hline R-Sq(adj) = 98\%, Akaike info criterion -0.690422,Schwarz criterion-0.431856,F- \\
statistic 569.754, Prob(F-statistic) 0.0000 \\
\hline *Significant at 1\% Level **Significant at 5\% Level***Significant at 10\% Level \\
\hline
\end{tabular}

According to the Co-integration regression output presented in the above table results such as adjusted $R^{2}$ is very high, Akaike info criterion, Schwarz criterion, Fstatistic, Prob(F-statistic) are appropriate. The model is when researcher turn in to the coefficient of determination, all the independent variables jointly explain the 98 percent of total variation of TR, it means this model is statistically appropriate to measure the relationship between economic performance and factors which affect to the Tourism receipts performance specially Foreign Direct Investment.
The model is overall significant at $1 \%$ level. Further, the long run regression output presented in the above table results all the sign of coefficient the variables are theoretically expected, further, the estimated coefficient of FDI indicates that, $1 \%$ increase of FDI will increase TR by $0.116 \%$. The long run relationship between FDI and TR has been positively and statistically significant at $5 \%$ level. The estimated coefficient of EX indicates that, $1 \%$ increase changes of EX will increase TR 1.46\%. The long run relationship between EX and TR has been positively and statistically significant at $1 \%$ level. Economic Freedom Index the negative coefficient and statistically not significant. The dummy variable indicated for war and nonwar period used in this study is positively and statistically significant at $1 \%$ level to determine TR in the long run.

\section{Results of Error Correction Model (ECM), - (TR: FDI)}

\begin{tabular}{|l|c|c|c|}
\hline Variable & Coefficient & t Value & Probability (p) \\
\hline$\beta_{0}$ (Intercept ) & 0.012476 & 0.161031 & 0.8732 \\
\hline D(FDI_LOG) & 0.099330 & 2.332319 & $0.0268^{* *}$ \\
\hline D(EX_LOG) & 0.417292 & 0.632183 & 0.5322 \\
\hline D(EFI_LOG) & -2.386280 & -2.090847 & $0.0454^{* *}$ \\
\hline D01 & 0.168418 & 1.712078 & $0.0976^{* * *}$ \\
\hline RESID01(-1) & -0.651912 & -2.875062 & $0.0075^{*}$ \\
\hline AR(1) & 0.487087 & 2.320633 & $0.0275^{* *}$ \\
\hline $\begin{array}{l}\text { F-Statistics 3.079303, Akaike info criterion -0.651498, Schwarz criterion - } \\
\text { 0.343591,Prob(F-Stat) } 0.0186\end{array}$ \\
\hline
\end{tabular}

*Significant at $1 \%$ Level **Significant at $5 \%$ Level $^{* * * \text { Significant at } 10 \% \text { Level }}$

According to the error correction model result show table 5.16 the model is adequate as $\mathrm{F}$ test statistics 3.079 with p-value 0.0186.The adjustment coefficient (0.651 ) with $p$-value 0.0075 . Adjustment speed coefficient of error correction term is statistically significant and has expected negative sign. The negative sign indicate that LTR moves downwardly towards equilibrium path. It implies that 65 percent of the deviation from the equilibrium are corrected each year. This shows the downward adjustment of LTR towards equilibrium path. However short run effect impact multiplier of LFDI is statistically significant at 5\% level and has expected sign. LEX variable is statistically not significant and LEFI, D variables are statistically significant in the short run period.

\section{Pairwise Granger Causality Tests on model forecasting Model (TR: FDI)}




\begin{tabular}{|c|c|c|c|c|}
\hline Null Hypothesis & Lag & $\begin{array}{c}\text { F- } \\
\text { Statistic }\end{array}$ & P-Value & $\begin{array}{c}\text { Granger } \\
\text { Causality }\end{array}$ \\
\hline $\begin{array}{c}\text { FDI does not } \\
\text { Granger Cause } \\
\text { TR }\end{array}$ & 2 & 28.7941 & $7.0 \mathrm{E}-08$ & Yes \\
\hline $\begin{array}{c}\text { TR does not } \\
\text { Granger Cause } \\
\text { FDI }\end{array}$ & 2 & 10.2020 & 0.00037 & Yes \\
\hline
\end{tabular}

The results shown in table 5.17 the causality does run from FDI to TR in Sri Lanka. According to the Granger Causality Tests, FDI statistically $(\mathrm{p}$ value $=$ 7.0E-08) motivated TR. TR statistically ( $\mathrm{p}$ value $=0.00037)$ motivated FDI. The results show that there are two way causal relationships from FDI to TR and from TR to FDI in Sri Lanka.

\section{E. Residual Distribution Forecasting Model}

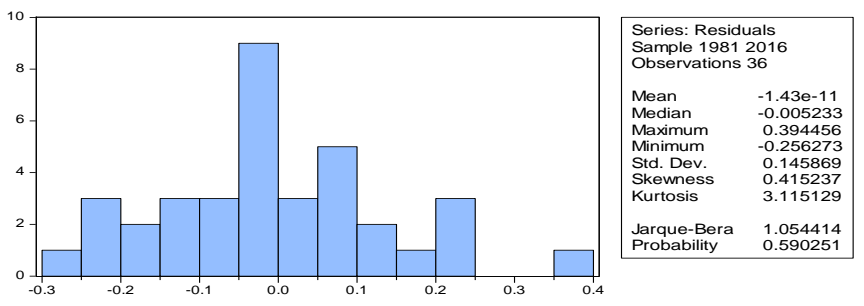

\section{F. The results of diagnostic tests based on the model}

\begin{tabular}{|c|c|c|}
\hline Tests & Statistics & Probability \\
\hline Jarque-Bera (normality test) & 1.054414 & 0.590251 \\
\hline $\begin{array}{l}\text { HeteroskedasticityTest: } \\
\text { ARCH }\end{array}$ & $\begin{array}{l}\mathrm{F} \quad \text { statistics } \\
0.421144 \\
\text { ObsR-squared } \\
0.441039\end{array}$ & $\begin{array}{l}0.5209 \\
0.5066\end{array}$ \\
\hline $\begin{array}{l}\text { Bruesh-Godfrey Serial } \\
\text { Correlation LM test: }\end{array}$ & $\begin{array}{l}\text { F } \text { statistics } \\
1.675605 \\
\text { ObsR-squared } \\
2.032706\end{array}$ & $\begin{array}{l}0.2061 \\
0.1539\end{array}$ \\
\hline
\end{tabular}

The model in the study has no non normality of errors, no autocorrelation, no heteroskedasticity, have well specified functional form and stable regressions. Therefore it can be concluded that the model applied in the study is robust and the specification of the model is an adequate representation of the data.

\section{G. Stability Test (Cusum) Forecasting Model}

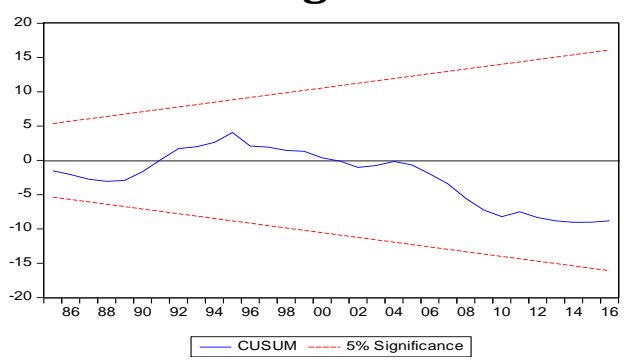

\section{H. Stability Test(Cusum of} quares) Forecasting Model

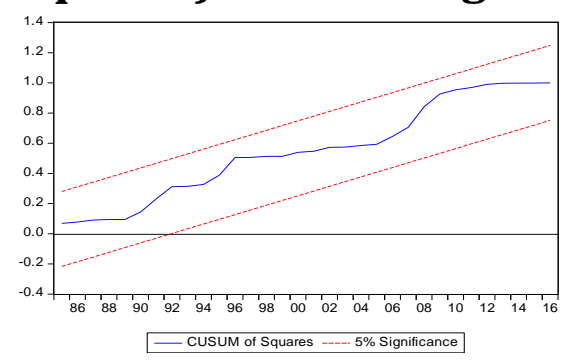

Cumulative sum and Cumulative sum of squares test using recursive residuals are preformed to examine the stability of the long run parameters. As the plots of the statistics for both tests lie within the critical bounds set for the 5 percent level, the hypothesis the regression equation is correctly specified is not rejected. It proves parameter stability. Residual diagnostics concerning autocorrelation, heteroskedasticity and normality indicate that the results are robust.

\section{v. Conclusion}

The main purpose of this study is to evaluate the impact of Foreign Direct Investment on Tourism Industry in Sri Lanka. This study used model to achieve the real goal of the research. To achieve its goal, the nonparametric approach that is graphical method, Confidence Ellipse, Kernal Fit, Nearest Neighbor fit to explore the relationship were used in this study. Then, parametric econometric techniques such as Co-integration analysis, Error correction model and Causality analysis are employed to investigate the relationship between FDI and Tourism industry. This study employs annual data for the period from 1978 to 2013 to evaluate the impact of foreign direct investment on tourism industry in Sri 
Lanka. Further, this study forecasted the data from 2014 to 2016 in order to find out the future potential of the contribution of FDI on tourism industry. Relationship between FDI on TR the long run relationship indicated that the FDI and TR have been positively and statistically significant at $5 \%$ level. The long run relationship between EX and TR has been positively and statistically significant at $1 \%$ level. The Relationship between FDI on TR model in short run, the adjustment speed coefficient of error correction term is statistically significant and has expected negative sign. According to the results of Granger Causality tests, in the models there are two way causal relationships.

\section{REFERENCES}

[1] Craigwell,R ., \& Winston, M. (2007). Foreign Direct Investment and Tourism in SIDS: Evidence from Panel Causality Tests. Retrieved from

https://www.academia.edu/1343836/Foreign_Direct_Invest ment_and_Tourism_in_SIDS_Evidence_from_Panel_Causa lity_Tests

[2] Chen,X.(2010). "The Influence of FDI on China's Tourism Industry", unpublished Master of Business Thesis, Auckland University of Technology. Retrieved from http://aut.researchgateway.ac.nz/bitstream/handle/10292/90 4/ChenX.pdf?sequence $=4$.

[3] Central Bank of Sri Lanka. (2014).Economics and Social Statistics of Sri Lanka. Colombo: Central Bank of Sri Lanka.

[4] David,J.T.,\& Richard,S.(2010).Tourism and Development in the Developing World. New York: Routledge.

[5] Dimitrios, K.,Taxiarchis, D.,\& Pantelis, P. (2007). Foreign direct investment and the tourism industry: The case of China. Retrieved from http://idec.gr/iier/new/3rd\%2 OPanhellenic\%20Conference/KYRKILIS-DELIS-

PANTELIDIS-FDI $\% 20$ AND $\% 20$

THE\% 20TOURISM\%20INDUSTRY-

\%20THE\%20CASE\%20OF\%20CHINA.pdfGeorgantopoul os,G,A. (2013).Tourism expansion and economic development: var/vecm analysis and forecasts for the case of india. Asian Economic and Financial Review, 3(4),464482 .

[6] Moore,W.M., \& Craigwel,R.C. (2008). Foreign direct investment and tourism in SIDS: evidence from panel causality tests. Retrieved from http://ideas.repec. org/p/pra /mprapa/33438.html.

[7] Ram, R., \& Zhang,H.K.(2002).Foreign Direct Investment and Economic growth: Evidence from cross-country data for the 1990s. Chicago: University of Chicago.

[8] Selvanathan, S., Selvanathan, E.A., \& Brida,V.(2009). Causality between Foreign Direct Investment and Tourism: Empirical Evidence from India. Retrieved from https://editorialexpress.com/cgibin/conference/download.cgi?db_name=ACE09 \&paper_id=230.

[9] Srinivas, P.S. (2008) . A Study on Foreign Direct Investment (FDI) in Indian Tourism. Retrieved from http://dspace.iimk.ac.in/bitstream/2259/544/1/107$113+$ srinivas.pdf

[10] Tourism Development Authority. (2013). Annual Report, Sri Lanka Tourism Development Authority, Colombo, Sri Lanka. Retrieved from http://www.sltda .lk/ statistics.

\section{About Author:}

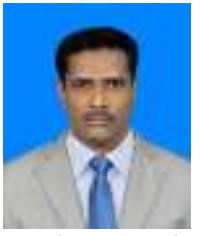

Dr. Abdul Majeed Mohamed Mustafa Voice: 0094 718035326
Presently, I have been serving as a Senior Lecturer, Grade-I at Department of Management, Faculty of Management and Commerce, South Eastern University of Sri Lanka. In total I have 17 years of working experience at this University since 1999. Currently, I am completed for $\mathrm{PhD}$ at University of Jaffna. As an academic, while I dedicated in teaching, learning, and research. I have also served as Directors of the Student Support Services and Welfare and Centre for External Degree and Professional Learning, Academic Warden, and Voluntary Coordinator for physically challenged students, Coordinator of the Disaster Management, students' counsellor and Secretary of Teachers' Union of the SouthEastern University. I have also actively involved in the development activities of this University at various levels. 